\title{
An Overview of The History of Serbian-British Relations
}

\begin{abstract}
The upcoming year, 2022, marks a jubilee - 185 years since the establishment of official diplomatic relations between the United Kingdom of Great Britain and Ireland at the very beginning of its Victorian era, and the Principality of Serbia at the beginning of its era of establishing statehood. In 1837, diplomatic and consular relations were established between the empire "on which the sun never sets" and the non-sovereign Serbian principality which was nominally autonomous within the framework and structure of the Turkish Ottoman Empire. The topic of this paper is an outlook on the history of relations between two old European nations - the Serbs ${ }^{1}$ and the English', the Anglo-Saxons or the British ${ }^{3}$, and two states - a great power and a colonial empire on the one hand, and a small but promising European country on the other.

Keywords: Serbia, Great Britain, the Balkans, Russia, great powers
\end{abstract}

1 There are several hypotheses and versions in the history of prehistory and the origin of Serbs. In general, it is considered indisputable that they were first mentioned in the 1st century in the works of Tacitus referring to their leader named Zorsines, who ruled around $50 \mathrm{BC}$, and also in the works of Pliny the Elder, mentioning that Serbian tribes were situated in Sarmatia above the Crimea and behind the Caucasus at the confluence of the Volga River into the Caspian Sea. The date of their immigration to the Balkans can be considered the year 550, when they first spent the winter south of the Sava and the Danube (according to the academic Simo Cirkovic) due to their poor power or the need to protect the borders, during the rule of the tolerant Byzantine emperor Maurice. It is indisputable that this date had been preceded by several Slavic incursions into the territory of Byzantium and that the flows of immigration lasted for centuries from the end of the 5th to the 8th century.

2 The Angles and the Saxons (and the Jutes) and later the Normans were Germanic peoples who inhabited the territory of Britain in the 5th century, suppressed the Celts (the Gauls), and then the Romans also formed the English as a people of a specific ethnic mixture.

3 The Indo-European Celtic (Gallic) tribes called the Britons inhabited the island in the 5th century BC. Britain is named after them. 


\section{Introduction}

The first encounter of the rulers of the two peoples and the two states took place in the city of Nis where the great prefect Stefan Nemanja and King Richard the Lionheart met during a crusade in which Philip II Augustus of Germany and Frederick I Barbarossa, the German king, also took part. "Nemanja allowed them to pass through his territories and provided assistance in the crusade" (Jovic, et al., 1990). Their occasional contacts during the new century lasted for more than 200 years, and in some segments even for much longer ${ }^{4}$, since the first new century contacts and diplomatic and political beginnings. It has been reported that the Kingdom of Serbia and the Kingdom of Great Britain officially established diplomatic relations when consul Sir George Lloyd Hodges (1790-1862), having come from Zemun, Austria, presented his credentials to Prince Milos ${ }^{5}$ in Kragujevac on 3 June 1837. Milos became a very close friend to Hodges, which was atypical of official diplomatic representatives of states, particularly the British ones. Hodges stayed in Serbia until 1839, which coincided with Milos's distancing from Russia due to its support for the defenders of the Constitution who sought to limit the Prince's power. Since then, intensive, uninterrupted (except for the period after the assassination of the Obrenovic royal couple in 1903), Serbian-British relations have continuously lasted and are approaching their two-century jubilee.

The prevailing political and historical narrative in Serbia is that throughout history the English have been deceitful to the Serbs as allies. Can these relations be perceived only as black and white, and can we be allowed to draw generalized and simplistic conclusions about relations between such a great imperial nation, significant for both the world and European history, with an equally old, state-building but smaller nation? ${ }^{6}$ An outlook on the history of Serbian-British relations, with a special review of culture and the history of economic flows, begins with the restoration of the Serbian state and freedom, after three and a half centuries

4 In the 17th century, a play about the siege, defence and fall of Belgrade to the Turks was performed at the Shakespeare's Globe theatre.

5 The conclusion of the Treaty of Friendship and Commerce between the two countries on 7 February 1870 is considered the formal moment of establishing diplomatic relations.

6 Smaller or small, but also an old nation, and in terms of history, statehood, culture, libertarianism and fighting spirit, a nation with a great history and a libertarian and persevering discourse it is characterized by. 
of Turkish rule, when British and Serbian interests coincided. In March 1807, the president of the Serbian government - the Governing Council, Prince Sima Markovic, made a fateful statement that Serbia considers itself an independent state. In the same month of the same year, Serbian diplomat Petar Icko returned from Constantinople and brought the news that the English had blockaded the city and that its fall was not far off. He claimed that it had been known and it had been ensured that, in the event of the capitulation of Constantinople, independence from Turkey had been envisaged for Serbia. "And that pleasing news certainly influenced the mood of the insurgents." (Corovic, 1989). The rivalry of the great powers over the influence in the Balkans has characterized the Serbian-British relations to this day. In an effort to suppress Russian influence, the English found their 'instrument' in Prince Milos. Since he had close relations with the English consul, Prince Milos believed that he would receive enough support to oppose Russia.

The political discourse of the relations between the English and the Serbs has been accompanied by the mystification of narratives, myths and prejudices about their relationship, an attempt to explain and underline the conclusions of Serbian historiography about historical regularity in the political history of relations between Serbia and Great Britain. And what is the historical regularity, characteristic, or differentia specificaif there is any - of international and interstate Serbian-British relations? What is the future of the assessment of these relations in the professional and general public is a question that logically arises. For example, the past $^{7}$ has shaped the regularity that Russian influence in the Balkans is a measure of the relationship between Great Britain and Serbia. If Serbian politics is complementary and close to the Russian one, then, as a rule, British politics is unfavourable for the Serbs and Serbia, and vice versa. All of it was determined by the political and historical axiom of British politics and British interests: sabotaged Russian influence in the Balkans (Serbia, Bulgaria, Montenegro and other southeast European countries, as well as in the Bosphorus region) in order to prevent Russian implementation in the Mediterranean and its access to warm seas. If Serbia is a Russian ally, then, as a rule, it is not a British favourite.

7 The so-called Crown Authority is a characteristic of both medieval England and medieval Serbia. Namely, countries in which district masters have never acquired such a degree of independence that they could establish states within a state (Kulauzov, 2019). 


\section{Establishing diplomatic relations}

The first British consul in Serbia, appointed on 30 January 1837, was George Hodges. The decision of the British government to establish a consulate in the autonomous Principality of Serbia, and not with the Ottoman Empire and the Turks, carried particular weight. For some time, Prince Milos was supported by Hodges in the fight against "Russian influence". It was a time of unusual circumstances, when absolutist Russia with its "autocracy" system (Russian: самодержавије) became the opponent of the personal regime in Serbia, and parliamentary England came to be its helper. The defenders of the Constitution also had England's support through France. During that period, England would have been glad if Serbia had its own access to the sea, and it supported the pan-Slavic programme of foreign and national policy of Serbia, the famous Nacertanije - presented by the nominal author Ilija Garasanin - which had initially been put on paper by British diplomat and publicist David Urquart, Czech Frantisek Alexandr Zach and Pole Adam Jerzy Czartoryski. Urquhart, for example, advocated update and implementation of Dusan's Code as the basis of new modern Serbian legislation.

It is worth mentioning that the new British consul, the one after Hodges, along with Garasanin defined the famous Fonblanque-Garasanin plan for the creation of the Viceroyalty of Serbia dating from 1853, which is the greatest international attempt to actualize and develop $\mathrm{Na}$ certanije. Serbia was internationally recognized at the Berlin Congress in 1878, and its interests were represented by Austria-Hungary. England also stood by Serbia, while Russia represented Bulgaria.

In modern history, Serbia waged a war of adventure against Bulgaria in 1885, when it was defeated at Slivnica. At the time, England advised Serbia to attack Turkey and liberate Old Serbia, Kosovo, Metohija, Sandzak and North Macedonia, which happened only 27 years later - in 1912. "Militarily unprepared and politically unmotivated", Serbia lost the only offensive war in its recent history. Owing to Austria-Hungary and England, Serbia did not have any consequences in terms of its territory. During the First World War, Great Britain and Serbia acted as allies for the first time, and their armies fought side by side. In 1914, Serbia accepted the controversial Austro-Hungarian ultimatum, but suggested that one controversial point be discussed before an impartial international forum 
in The Hague (Radojevic, et al., 2014). Russia, England, France and Italy took numerous steps to prevent the First World War.

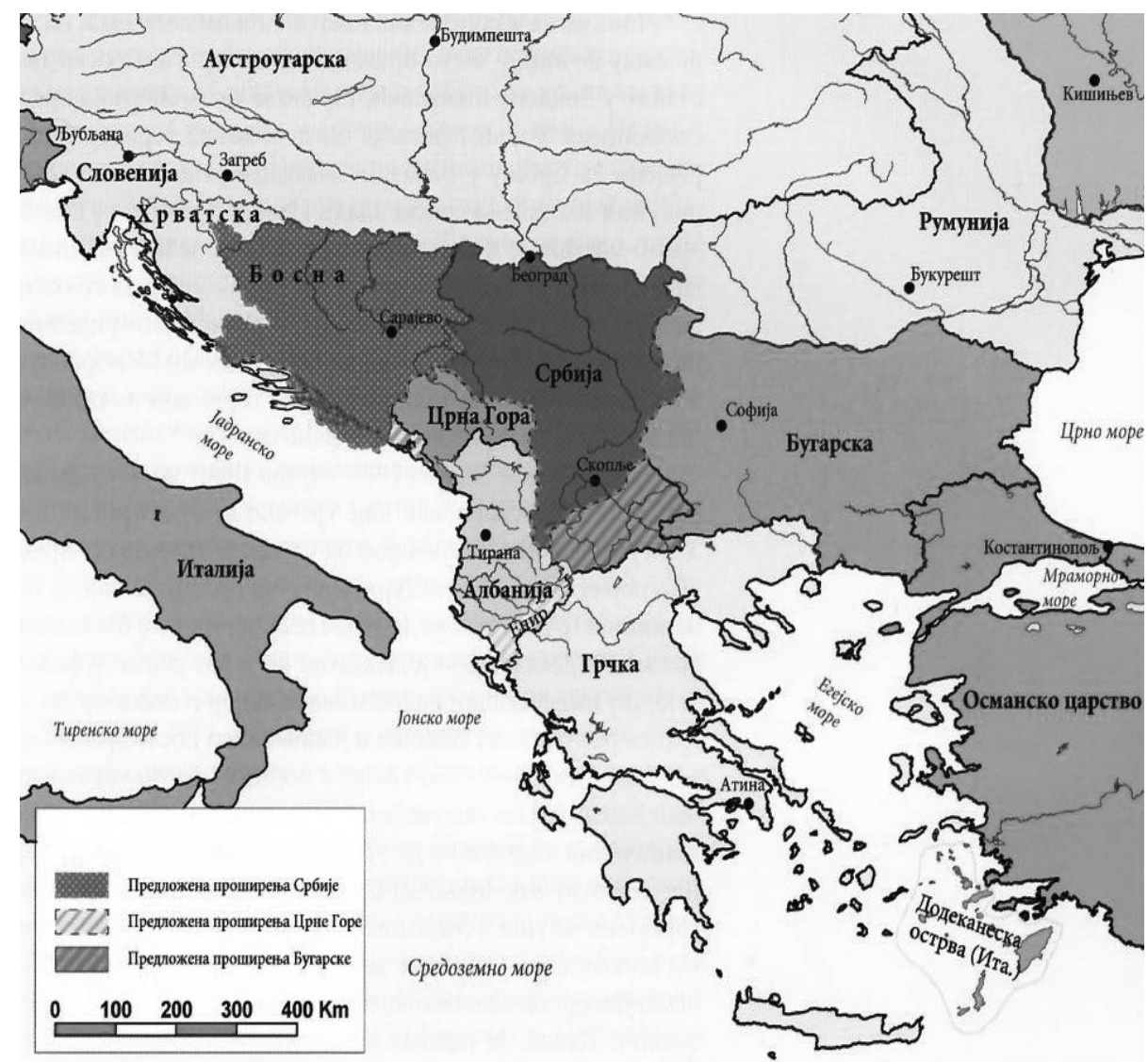

The borders proposed by Aide-Memoire of 28 July 1915, in accordance with point 5 of the Entente's Secret London Treaty of 26 April 1915, "whose territory will be doubled in size after the war and a large coastline will be added to it and Montenegro." (Gray p. 127. C. Antic)

After Franz Ferdinand of Austria (Franz Ferdinand von Österreich-Este), heir presumptive to the Austro-Hungarian throne, was assassinated on June 28 by Yugoslav nationalists, idealists and revolutionaries, the English historian A. J. P. Taylor wrote that such Ferdinand's move was tantamount to as if the British sovereign irrationally decided to parade through Dublin on St. Patrick's Day. (Radojevic, et al., 2014: 73). Vienna, crucially encouraged by Berlin, did not miss the opportunity to make use of this assassination to start the long-awaited war against 
Serbia and, having invented the news that the Serbian army opened fire near Kovin, Austria-Hungary, after Serbia rejected the ultimatum (which, according to British Foreign Secretary Gray is "the most formidable document ever seen addressed by one state to another that was independent"), declared war on Serbia on 28 July 1914, and then, after the incursion into Belgium, Great Britain entered the war against Germany and Austria-Hungary as a collateral Serbian ally, along with Russia and France. Afterwards, Italy, Romania, and the United States of America joined the Entente forces, fighting against Germany, Austria-Hungary, Bulgaria, and Turkey.

\section{Economic and commercial relations}

The British government was particularly interested in obtaining mining concessions and leases. Even Vuk Karadzic mediated in favour of a company from Wales to obtain a concession for copper ore. In the second stage, British tenants became interested in obtaining concessions for the mines of iron, coal, copper, lead, silver and zinc, as well as concessions for navigation on the Danube. In the eighth decade of the 19th century, two particularly important agreements were concluded: the Interim Trade Convention and the Treaty of Friendship and Commerce between Great Britain and the Kingdom of Serbia. After the opening of the Belgrade-Thessaloniki railway, the possibilities of importing British goods became particularly favourable. The subjects of this treaty of 7 February 1880 are basically the following: recognition of the status of a privileged nation, the right to acquire property over real estate, customs rates, taxes, etc.

The most important British export products to Serbia were: metals and metal products, tools and blades of all kinds, implements and machines for agriculture, weaving and sewing yarns, yarn products of all kinds, pottery and porcelain goods, refined mineral oils. The customs tariff was $8 \%$ and $10 \%$ of their value. The main Serbian export items of that time were pigs and prunes.

The Treaty of Commerce governed the issues of maritime and river traffic and consular representatives. However, the main significance of this agreement is that it confirmed the independence of Serbia and equality in international relations. 


\section{World War I, Political, Commercial and Diplomatic Relations - the Secret Treaty of London and Greater Serbia}

The ultimatum sent to Serbia was described by British Foreign Secretary Sir Edward Gray as "the most formidable document I have ever seen addressed by one state to another that was independent". A similar conclusion was reached by Sir Winston Leonard Spencer Churchill, Prime Minister Herbert Henry Asquith and King George V (of the United Kingdom). The German assessment was that "Great Britain has no interest in interfering because of some Balkan country".

With regard to trade, Britain had not received a single significant order from Serbia and the Serbian army until 1914, but it did help Austria-Hungary win the Customs War against the Kingdom of Serbia, which lasted until 1911. Serbia, expanding into new markets, shifted the export focus to British Malta, which resulted in the fact that exports from Serbia to Britain, via Malta, increased 75 times.

During the First World War, Great Britain and the Kingdom of Serbia were allies. Admiral Ernest Tubric commanded a battery of coastal cannons that defended Belgrade in 1915. As a commander of the British military mission, he retreated across Albania with the Serbs, fought in the Salonica front and entered liberated Belgrade in 1918.

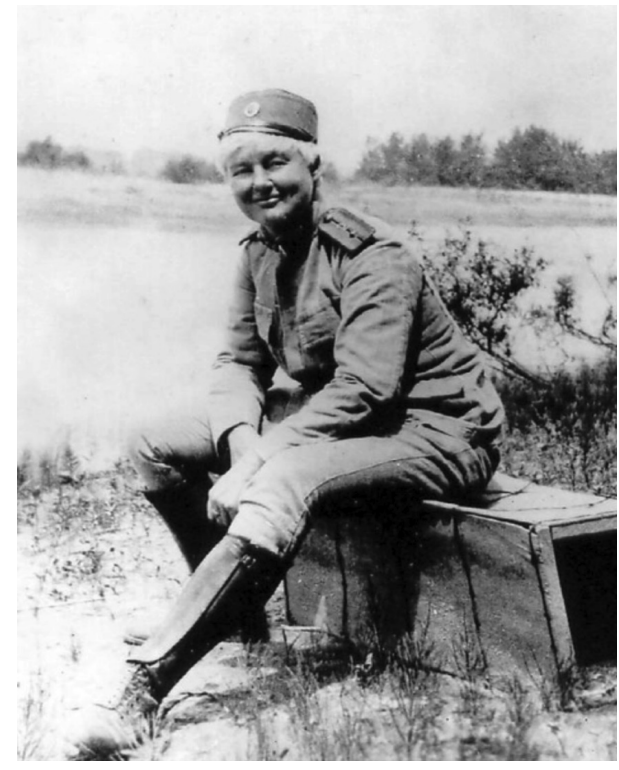

Flora Sandes (January 22, 1876 November 24, 1956) a British nurse and the only woman officer in the Serbian army of the Kingdom of Serbia during the First World War. She was awarded seven medals. 
Flora Sands was the only female officer in the Serbian army in the First World War, a volunteer of the legendary Serbian "Iron Regiment". She was one of several hundred British women who came to Serbia voluntarily in 1914 as nurses - members of medical missions, who joined thirty British doctors and fearlessly fought against epidemic typhus, thus setting an epic example of beneficence. This led to an increase in the volume of economic exchange by four times after the First World War.

In 1940, efforts to exploit Yugoslav sources in Belgrade for information about Austria and Czechoslovakia produced negligible results, but in the spring of 1941 both the Secret Intelligence Service and the Special Operations Executive (the two organisations working closely together here), mobilised their political and military contacts in the country behind the coup of 27 March 1941, which deposed the pro-Axis Regent, Prince Paul, in favour of a pro-Allied regime. As elsewhere, too, secure radio communications of the Secret Intelligence Service were used to transmit appeals for help from beleaguered local forces. At the beginning of March, for example, Archibald Gibson sent a plea from General Stojanovic, the Assistant War Minister and an 'old acquaintance', for British arms, without which 'they had no possibility of offering effective resistance to any German attack'. The coup was a tremendous British propaganda success, though unfortunately short-lived as it also precipitated the German invasion of both Yugoslavia and Greece. But the Secret Intelligence Service was able to give a warning to Belgrade. At 10:20 a.m. on 5 April 1941, drawing on signals intelligence (though disguising it as a human source), Menzies sent a message to Gibson: 'Inform Yugoslav General Staff that from a very reliable agent we learn that German attack will begin early tomorrow morning.' The invasion, in fact, began at 5:15 a.m. (Jeffery, 2010: 415).

In March 1940, Frederick William Winterbotham complained that the intelligence position regarding Italy was 'lamentable'. 'I cannot believe', he wrote, 'that Italian Air Force officers in Budapest, Italian engineers and merchants in Belgrade and Sofia are all unapproachable. This is the side from which we need to penetrate since the French use their own opportunities to the utmost.' By early May, the situation had not improved.' (Jeffery, 2010: 423). 


\section{March was not paid by the British government}

27 March was the day when reason gave way to emotions. On that day, patriots of various political colours - all political parties except Ljotic Assembly - volunteer groups, communists, nationalists, British and Soviet people in the army staged anti-war demonstrations, following the coup d'etat the night before, and after the signing of the Triple Alliance. It was the first historical step in the later alliance of Britain and the USSR and a conscious Serbian sacrifice to encourage the Allies to defeat Nazism in 1945. All social strata and groups supported the coup and took part in the demonstrations - all political organizations except Ljotic's followers, including Patriarch Gavril Dozic and members of SKOJ (League of Communist Youth of Yugoslavia), monarchists and republicans, Russophiles, Francophiles, Anglophiles, intellectuals gathering at salons, students, workers and sons of peasants. There is not a single piece of evidence that any foreign government or its intelligence service organized and was able to stage such an event that could have only flared up from a collective identity based on the archetypal libertarian spirit of the Serbian people and their collective national pride. The provisions of the Triple Alliance were not made public, therefore the provision "neither the transport of troops nor the transport of war material' was not known. No documents were published in the British archives about this event and its possible contribution to the coup. It is true that the British government donated 300,000 pounds to the Republican Club and the Agrarian Party, but these were salon academic political clubs, a counterpart to today's influential "think-tank" groups and politically impotent parties like the Civic Alliance or New Democracy were in Serbia in the 1990s. Therefore, 27 March was an authentic, original act of Serbs. One can speak of Soviet and British contributions, but by no means of someone 'paying Serbs to be ardent patriots and anti-Nazis!' There is simply not a single relevant historical piece of evidence for this pseudomyth. On that occasion, Winston Churchill stated 'Early this morning the Yugoslav nation found its soul'.

In the Second World War, Great Britain cooperated with both guerrilla liberation and anti-Nazi movements in Serbia, but at the end of the war, it opted for definitive cooperation and support of the partisan movement led by Tito, and discontinued its cooperation with the monarchist movement led by Draza Mihailovic. 


\section{Conclusion}

If a historical regularity characterizing the relations between Great Britain $^{8}$ and Serbia ${ }^{9}$ can be deduced, it would be a relationship between a great power, a colonial empire, a superpower on the one hand and a relatively small but old country, rich in state-building tradition and history on the other, a country with a great and significant role in the history of Europe, including a state and a nation with a high level of self-esteem and libertarian national pride. The discourse that claims there are no eternal friends or eternal enemies in international and interstate relations, and that only interests are eternal, has been confirmed in the case of British-Serbian relations. Looking at different historical stages, it can be concluded, for example, that the Victorian era was predominantly marked by good, sometimes seemingly close and 'allied' relations between the two states. After the severance of diplomatic relations in 1903 due to the assassination of King Aleksandar Obrenovic, they were re-established, and followed by the era of involuntary alliance (precisely diagnosed by academician Ekmecic) during the First World War. After the Great War and good but anesthetized relations between the two world wars, the inter-dynastic connections and cultural ties of the two peoples did not have a significant impact on British politics, nor did the Serbian diaspora in Great Britain during and especially after the Second World War. The decisive influence of the English on the March coup is overemphasized; it is simply an imaginary myth, unsupported by evidence. The British did not bribe the youth, the Serbian Orthodox Church headed by the patriarch, students, pupils, intellectuals, mainly officers and political parties, workers, officials, peasants, i.e. all social strata. The indicator and generator of the anti-German coup and demonstrations was the archetypal Serbian libertarian code, no matter how reckless it was. There are serious opinions that the coup was a fatal Serbian historical error that would not have happened if the contents of the Pact had been published: 'neither the transport of troops nor the transport of war material.' Namely, it seems that it is almost impossible to find a conclusion in Soviet historiography before, and in

8 Great Britain (established by the Acts of Union 1707) is in this text synonymous with the United Kingdom and the United Kingdom of Great Britain and Northern Ireland

9 (Principality of Serbia, Kingdom of Serbia, Kingdom of Yugoslavia, Socialist Federal Republic of Yugoslavia and Federal Republic of Yugoslavia, Republic of Serbia) 
Russian historiography now, that the April war led to the postponement of Operation Barbarossa. It is the same with British historiography and journalism.

Russia is differentia specifica in Serbian-British relations. When Serbian-Russian relations are at a higher level of closeness and friendship, and when Russian influence is greater, then British-Serbian relations are worse and vice versa. This regularity has been confirmed almost scientifically over the past two hundred years, as long as the history of Serbian-British relations has lasted. This was the case from the time of the first Consul Hodges and Prince Milos, through the periods of the second rule of Prince Milos and the reign of Prince Mihailo, the Eastern crisis, the Serbian-Turkish wars (1876-1878), the Berlin Congress in 1878, the Serbian-Bulgarian war in 1885, in the period 1914 - 1918. Just before the Serbian attack on Bulgaria in 1885, the English advised King Milan to turn the army towards Old Serbia, more precisely the Kumanovo, Skopje and Kosovo areas, and liberate them, which Great Britain would support. Also, in 1885, along with Austria, Great Britain helped Serbia avoid having any territorial penalties and war reparations due to its military defeat. It should be reminded that official Russia was the mentor of San Stefano's Greater Bulgaria at that time. Therefore, the thesis that 'the English have always betrayed us' fails the test of history. Because, as soon as Russia promotes non-Serbian interests, Britain occupies 'the Balkans undefended chess field'. The conclusion of this review of the history of Serbian-British relations is that good relations between Great Britain and Serbia have been induced by endemic Anglo-Russophobia in such a way that they are inversely proportional to close and coherent Serbian-Russian relations, i.e. by preventing Russian influence on internal affairs in Serbia, as part of the British Mediterranean strategy. 


\section{References}

1. Aleksandar Rastović, (2000). Velika Britanija i Srbija 1878-1889, Istorijski institut Srpske akademije nauke i umetnosti, Beograd.

2. Aleksandar Rastović, (2005). Velika Britanija i Srbija 1903-1914, Istorijski institut Srpske akademije nauke i umetnosti, Beograd.

3. Borislav Pekić, (1978). Sentimentalna istorija Velike Britanije, Mala enciklopedija, Prosveta, Beograd.

4. Branislav Otašević, (2013). Milovan Đilas skice za portret, Književna zadruga Srpskog narodnog vijeća Crne Gore, Beograd.

5. Vladimir Corović, (1989). Istorija Srba, BIGZ, Beograd.

6. Vladimir Ćorović, (1997). Istorija Srpskog naroda, Ars Libri, Beograd.

7. Grupa autora, prvo izdanje (1981-1993); drugo izdanje (1994); treće izdanje (2000). Istorija srpskog naroda (I-VI), Srpska književna zadruga, Beograd.

8. Dragoljub Živojinović, (2011). Nadmeni saveznik $i$ zanemareno srpstvo: britansko-srpski odnosi 1875-1941, Albatros plus, Beograd.

9. Maša Kulauzov, (2019). Opšta pravna istorija, Pravni fakultet, Centar za izdavačku delatnost, Novi Sad.

10. Milorad Ekmečić, (2013). Dugo kretanje između klanja i oranja, Istorija Srba u novom veku 1492-1992, Evro Giunti, Beograd.

11. Mira Radojević, Ljubodrag Dimić, (2014), Srbija u velikom ratu 1914-1918, Srpska književna zadruga, Beograd.

12. Momir Jović, Kosta Radić, (1990). Srpske zemlje i vladari, Društvo za negovanje istorijskih vrednosti, Kruševac.

13. Sima Avramović, (2018). Uporedna pravna tradicija, Univerzitet u Beogradu Pravni fakultet, Centar za izdavaštvo i informisanje, Beograd.

14. Čedomir Antić, (2012). Neizabrana saveznica: Srbija i Velika Britanija u Prvom svetskom ratu, Zavod za udžbenike, Beograd.

15. Christopher Clark, (2012). The Sleepwalkers. How Europe Went to War in 1914, Penguin

16. Henri Kisindžer, (2017). Diplomatija, Nova knjiga, Podgorica.

17. Keith Jeffery, (2010). MI6: The History of the Secret Intelligence Service 1909-1949, Bloomsbury publishing Plc, London.

18. Michael Martens, (2020). U požaru svetova, Ivo Andrić - jedan evropski život, Laguna, Beograd. 
Миљкан КАРЛИЧИЋ

Адвокат, Београд

ДОИ: 10.5937/bezbednost2102057K УДК: 327(497.11:410) 1837/1941

Прегледни научни рад

Примљен: 1. 7. 2021. године

Ревизија: 16. 8. 2021. године

Датум прихватања: 7. 9. 2021. године

\section{Осврт на историјат српско-британских односа}

Anстракт: Следеће, 2022. године навршава се јубилеј - 185 година од успостављана званичних дипломатских односа између Уједињеног Краљевства Велике Британије и Ирске на самом почетку викторијанског доба, и Кнежевине Србије на почетку доба успостављаға државности. Године 1837. успостављени су дипломатско-конзуларни односи између империје „у којој сунще никад не залази" и несуверене српске кнежевине, номинално аутономне у оквиру и саставу турског Османског иарства. Тема овог чланка јесте поглед на историју односа два стара европска народа Срба ${ }^{1}$ и Енглеза ${ }^{2}$, Англосаксонаца или Британаца ${ }^{3}$, и две државе -c једне стране, велике силе и колонијалне империје, а с друге стране, мале али перспективне европске земье.

Кључне речи: Србија, Велика Британија, Балкан, Русија, велике силе

1 У историји, о пореклу и праисторији Срба постоји више хипотеза и верзија. Углавном се као неспорно узима да су први пут поменути у 1 . веку у Тацитовим делима, преко њиховог вође по имену Зорсин, који је владао око 50. године старе ере, и код Плинија Старијег, који српска племена лоцира у Сарматији изнад Крима и иза Кавказа на ушћу реке Волге у Каспијско језеро. Као година досељавања на Балкан може се узети 550. година, када су (по академику Сими Ћирковићу) први пут презимили јужно од Саве и Дунава, за време толерантног (из немоћи или потребе заштите граница) византијског цара Маврикија. Неспорно је да је томе претходило више таласа словенских упада на територију Византије и да је досељавање у таласима трајало од краја 5. до 8. века.

2 У Англи и Саси (и Јити), а касније Нормани, германски су народи који су у 5. веку населили територију Британије, потиснули Келте (Гале), а потом су и Римљани образовали Енглезе као народ специфичне етничке мешавине.

3 Индоевропска келтска (галска) племена Брити насељавају острво у 5. веку старе ере. По њима Британија носи име. 


\section{Увод}

Први сусрет владара два народа и две државе десио се у Нишу између великог жупана Стефана Немање и краља Ричарда Лавље Срце (Richard Lionheart) у време крсташког похода у ком су учествовали и француски краљ Филип II Август (Philippe II Auguste) и немачки краљ Фридрих I Барбароса (Friedrich I). „Немања им дозвољава пролаз кроз своје територије и пружа помоћ у походу“ (Јовић et al., 1990). Њихови нововековни спорадични контакти трају више од двеста година, а у неким сегментима и знатно дуже ${ }^{4}$, још од првих нововековних контаката и дипломатскополитичких почетака. Као званичан почетак наводи се година када су Краљевина Србија и Краљевина Велика Британија успоставиле дипломатске односе предајом акредитивног писма - 3. јуна 1837. године у Крагујевцу конзул Џорџ Лојд Хоџиз (Sir George LIoyd Hodges; 1790-1862) предао је писмо кнезу Милошу, код којег је дошао из Аустрије из Земуна ${ }^{5}$. Са Хоџизом ће Милош, што је несвојствено званичним дипломатским представницима држава, а посебно британским, постати врло близак пријатељ. У Србији ће боравити до 1839. године, а то ће се поклопити са Милошевим удаљавањем од Русије због њене подршке уставобранитељима који су тежили ограничавању кнежевске власти. Од тада интензивне, непрекинуте (изузев периода после атентата на краљевски пар Обреновић 1903. године) српско-британске релације трају у континуитету, приближавајући се двовековном јубилеју.

У Србији преовлађује политички и историјски наратив да су Србима кроз историју Енглези варљиви као савезници. Да ли се те релације могу гледати само кроз црно-белу представу и да ли се сме дозволити давање уопштених и једноставних закључака при свођењу односа између једног, по значају на историјској светској и европској позорници, великог империјалног народа, са исто тако старим, државотворним, али мањим народом ${ }^{6}$ Поглед на историјат српско-британских односа, са посебним освртом на

4 У Шекспировом позоришту Глоуб у 17. веку играна је представа о опсади, одбрани и паду Београда под Турке.

5 Као формални тренутак успостављања дипломатских односа узима се и закључивање Уговора о пријатељству и трговини између две земље 7. 2. 1870. године.

6 Мањим или малим, али такође старим народом, а по историји, државности, култури, слободарству и борбености, народом са великом историјом и слободарским и жилавим дискурсом. 
културу и историју привредних токова, почиње обнављањем српске државе и слободе након три и по века турске владавине, када су се подударили британски и српски интереси. У марту 1807. године председник српске владе (Управног савета) кнез Сима Марковић дао је судбоносну изјаву да Србија себе сматра независном државом. Истог месеца те године вратио се из Цариграда посланик Петар Ичко, који је донео вест да Енглези врше блокаду Цариграда и да његов пад није далеко. Тврдио је да се знало и да је сигурно да је, у случају капитулације Цариграда, за Србију предвиђена независност од Турске. „И та пријатна вест утицала је свакако на расположење устаника“" (Ћоровић, 1989). Иначе, супарништво великих сила око утицаја на Балкану карактерише српско-британске односе и данас. У тежњи да сузбију руски утицај, Енглези су своје „оруђе“ пронашли у кнезу Милошу. Будући да је са енглеским конзулом био у присним односима, кнез Милош је веровао да ће добити подршку довољну да се одупре Русији. Политички дискурс о односу Енглеза и Срба прате мистификација наратива, митова и предрасуда, покушај објашњења и подвлачење закључака српске историографије о историјским законитостима у политичкој историји односа Србије и Велике Британије. А постоји ли и која је историјска законитост, differentia specifica међународних и међудржавних српско-британских односа? Каква је будућност оцене тих односа у стручној и општој јавности, питање је које се логично намеће. На пример, прошлост7 је обликовала закономерност да је руски утицај на Балкану мера односа Велике Британије и Србије. Уколико је српска политика комплементарна и блиска руској, онда је, по правилу, британска политика неповољна по Србе и Србију, и обрнуто. Све је одредио политичко-историјски аксиом британске политике и британских интереса: саботирани руски утицај на Балкану (Босфору, Србији, Бугарској, Црној Гори и осталим земљама европског југоистока) како би била онемогућен улазак Русије на Средоземље и излазак на топла мора. Уколико је Србија руски савезник, онда, по правилу, није британска миљеница.

7 Такозвани крунски вазалитет је карактеристика и средњовековне Енглеске и средњовековне Србије. Наиме, земље у којима обласни господари никада нису стекли такав степен самосталности да би могли да образују државе у држави (Кулаузов, 2019). 


\section{Успостављање дипломатских односа}

Први конзул Велике Британије у Србији, именован 30. јануара 1837. године, био је Џорџ Хоџиз. Одлука британске владе да оснује конзулат у аутономној Кнежевини Србији, а не код Османског царства и Турака, имала је посебну тежину. Код Хоџиза је једно време кнез Милош нашао ослонац у борби против „руског утицаја“. Било је то време необичног стицаја околности, када је апсолутистичка Русија са системом самодержавије постала противник личног режима у Србији, а парламентарна Енглеска његов помагач. И уставобранитељи су преко Француске имали подршку Енглеске. У том периоду би Енглеска радо Србију видела са излазом на море и подржала је пансловенски програм спољне и националне политике Србије, чувено Начертаније номиналног аутора Илије Гарашанина, кога је на папир први ставио британски дипломата и публициста Дејвид Уркварт (David Urquart), као и Чех Франтишек Зax (František Alexandr Zach) и Пољак Адам Чарторијски (Adam Jerzy Czartoryski). Уркварт је, на пример, заговарао новелирање и имплементацију Душановог законика као основу модерног новог српског законодавства.

Ваља поменути и да је нови британски конзул, после Хоџиза, дефинисао са Грашанином чувени Фонбланк-Гарашанинов план о стварању поткраљевине Србије из 1853. године, што је највећи међународни покушај остварења и развијања Начертанија. Србија је међународно призната 1878. године на Берлинском конгресу, а њене интересе је заступала Аустроугарска. Иза Србије је стајала и Енглеска, а Русија је заступала Бугарску.

Србија је у модерној историји водила један авантуристички рат, и то 1885. године против Бугарске, када је доживела пораз на Сливници. Савет Енглеске био је да Србија нападне Турску и ослободи Стару Србију, Косово, Метохију, Санџак и Северну Македонију, што је она учинила тек 27 година касније - 1912. године. „Војнички неспремна, а политички немотивисана“, Србија је тај једини нападачки рат у својој новијој историји изгубила. Захваљујући Аустроугарској и Енглеској, Србија је прошла без територијалних последица. Током Првог светског рата Велика Британија и Србија први пут су наступиле као савезнице, а њихове војске су се бориле раме уз раме. Србија је 1914. године прихватила спорни аустроугарски ултиматум, али је за 
једну тачку предлагала да се о њој расправља пред непристрасним међународним форумом у Хагу (Радојевић, et al., 2014). Русија, Енглеска, Француска и Италија предузимале су многе кораке да се Први светски рат предупреди.

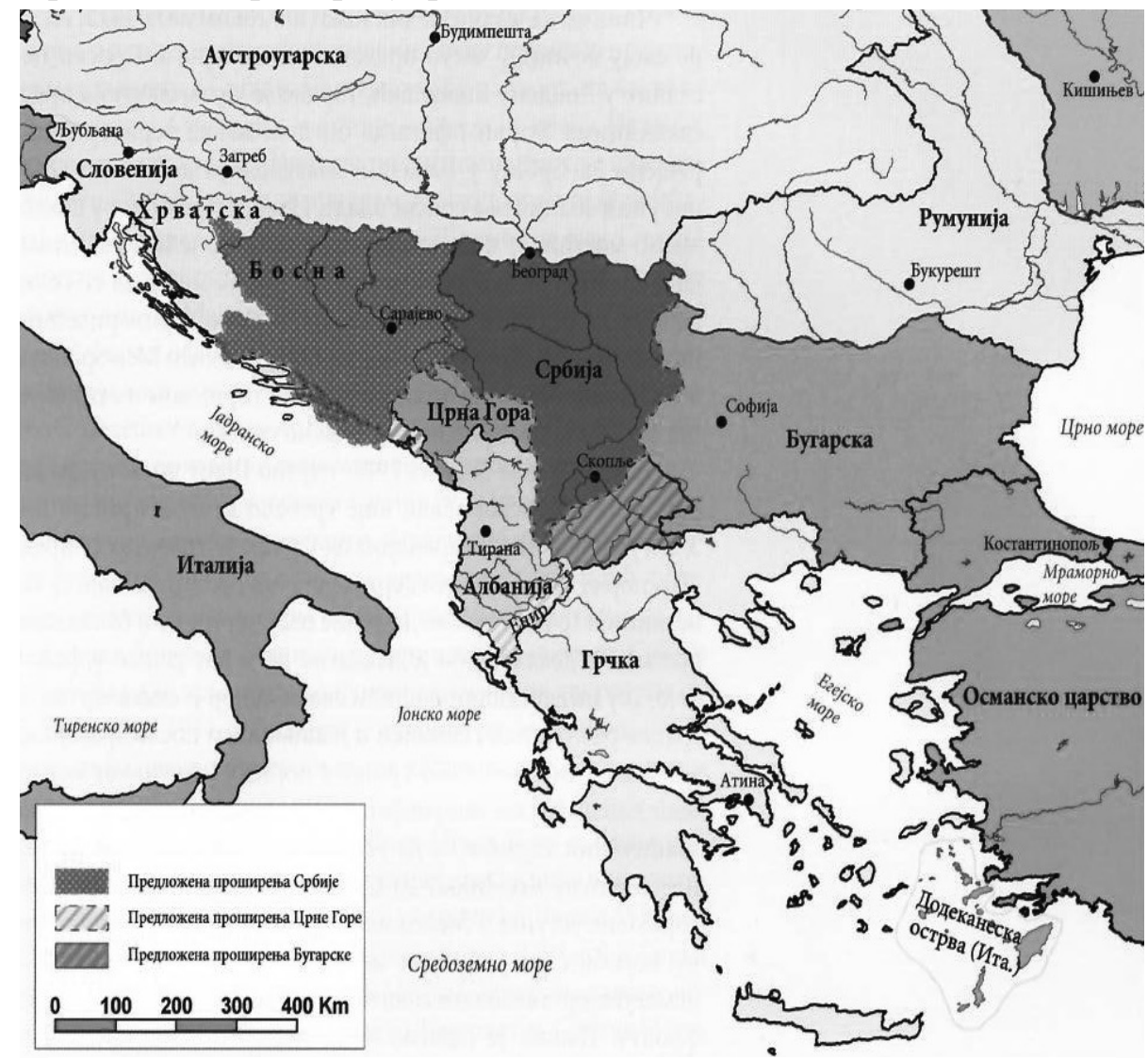

Границе предложене савезничким ед-мемоаром од 28. јула 1915. у складу са тачком 5 Антантиног тајног лондонског уговора од 26. априла 1915: ,„... чија ће територија после рата бити удвостручена док ће њој и Црној Гори бити присаједињен велики појас морске обале“. (Греј стр. 127. Ч. Антић)

Након атентата на аустроугарског престолонаследника Франца Фердинанда (Franz Ferdinand von Österreich-Este) 28. јуна од стране југословенских националиста, идеалиста и револуционара, енглески историчар А. Џ. П. Тејлор упоредио је Фердинандов поступак са евентуалном ирационалном одлуком британског суверена да парадира Даблином на Дан Св. Патрика (Радојевић, et al., 2014:73). Беч, уз 
одлучујући подстрек Берлина, није пропустио прилику да атентат искористи за дуго чекани рат против Србије. Имисливши вест да је српска војска отворила ватру код Ковина, Аустроугарска је након одбијања ултиматума који је, према британском министру спољних послова Греју, „најужаснији документ који икада једна независна држава уручила другој сувереној држави“, објавила рат Србији 28. јула 1914. године. Након немачког напада на Белгију, у рат против Немачке и Аустроугарске ушла је, поред Русије и Француске, и Велика Британија, као колатерални српски савезник. Касније су се силама Антанте придружиле и Италија, Румунија и Сједињене Америчке Државе, ратујући против Немачке, Аустроугарске, Бугарске, и Турске.

\section{Привредни и трговински односи}

Влада Велике Британије је била посебно заинтересована за добијање концесија и закупа у рударству. Чак је и Вук Караџић посредовао у корист једног друштва из Велса за добијање концесије за руду бакра. У другој фази британски закупци су се заинтересовали за добијање концесија за руднике гвожђа, угља, бакра, олова, сребра и цинка, као и концесије за пловидбу Дунавом. У осмој деценији 19. века закључена су и два посебно важна уговора: Привремена трговачка конвенција и Уговор о пријатељству и трговини између Велике Британије и Краљевине Србије. После отварања пруге Београд-Солун могућности пласмана британске робе постале су посебно повољне. Предмети овог уговора од 7. фебруара 1880. године у основи су следећи: признавање статуса повлашћене нације, право над стицањем својине над непокретностима, царинске стопе, порези и сл.

Најважнији британски производи који су се извозили у Србију били су: метали и металне прерађевине, алати и сечива сваке врсте, оруђа и машине за пољопривреду, предива за ткање и шивење, прерађевине од предива сваке врсте, лончарска и порцеланска роба и минерална пречишћена уља. Царинили су се са $8 \%$ и $10 \%$ њихове вредности. Главни српски извозни артикли тог времена биле су свиње и суве шљиве.

Трговачким уговором регулисана су питања поморског и речног саобраћаја и конзуларних представника. Али главни значај овог споразума јесте то што је њиме потврђена независност Србије и њена равноправност у међународним односима. 


\section{Први светски рат, политички, трговачки и дипломатски односи - тајни лондонски пакт и велика Србија}

Ултиматум упућен Србији министар Едвард Греј (Sir Edward Gray) описао је као „најужаснији документ који је икада упућен једној независној држави од стране друге“. Сличан је закључак и Винстона Черчила (Sir Winston Leonard Spencer Churchill), премијера Херберта Асквита (Herbert Henry Asquith) и краља Џорџа V (George V of the United Kingdom). Немачка процена је била да „Велика Британија нема интереса да се умеша због неке балканске земље“.

По питању трговинске размене Британија све до 1914. године није од Србије и српске војске примила ниједну озбиљнију поруџбину, али је зато помогла Аустроугарској да победи у Царинском рату против Краљевине Србије, који је трајао до 1911. године. Србија је, освајајући нова тржишта, тежиште извоза преместила на британску Малту, тако да је извоз из Србије у Британију, преко Малте, повећан 75 пута.

У току Првог светског рата Велика Британија и Краљевина Србија биле су савезнице. Адмирал Ернест Тубрич командовао је батеријом обалских топова који су бранили Београд 1915. године. Као командант британске војне мисије прешао је са Србима Албанију, био на Солунском фронту и ушао у ослобођени Београд 1918. године.

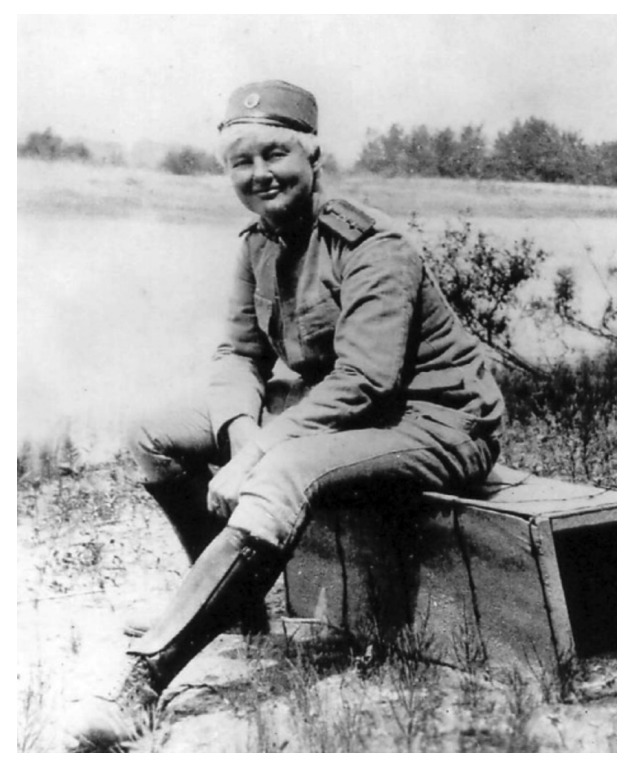

Флора Сандс (Flora Sandes) (22. јануар 1876 - 24. новембар 1956) британска болничарка и једина жена офииир српске војске Краљевине Србије за време Првог светског рата. Одликована је са седам медаьь. 
Флора Сандс, једина жена официр српске војске у Првом светском рату, добровољац легендарног српског Гвозденог пука, једна је од више стотина Британки које су 1914. године добровољно дошле у Србију као медицинске сестре - чланице медицинских мисија, које су се придружиле тридесеторици британских лекара и као лавице се бориле против пегавог тифуса дајући епски пример милосрђа. Захваљујући томе, после Првог светског рата обим привредне размене повећан је четири пута.

У Београду су 1940. године напори да се југословенски извори користезаинформацијеоАустријииЧехословачкојдализанемарљиве резултате, али су у пролеће 1941. године и Тајна обавештајна служба (Secret Intelligence Services) и Управа за специјалне операције (Special Operations Executive) - две организације које овде блиско сарађују - мобилисале своје политичке и војне контакте у земљи да подрже пуч којим је 27. марта 1941. године свргнут проосовински регент принц Павле у корист просавезничког режима. Као и другде, безбедна радио-комуникација Тајне обавештајне службе коришћена је за слање апела за помоћ изнемоглим локалним снагама. На пример, почетком марта, Арчибалд Гибсон (Archibald Gibson) упутио је молбу генералу Стојановићу, помоћнику министра и „старом познанику“, за британско оружје, без којег „нису имали могућност пружања ефикасног отпора било ком немачком нападу“. Пуч је био изузетан британски пропагандни успех, мада нажалост краткотрајан, јер је подстакао немачку инвазију на Југославију и Грчку. Али Тајна обавештајна служба могла је да упути упозорење Београду. У 10 сати и 20 минута пре подне, 5. априла 1941. године, ослањајући се на обавјештајне сигнале (иако их прикривајући као људски извор), Мензис је Гибсону послао поруку: „Обавестите југословенски генералштаб да од врло поузданог агента сазнајемо да ће немачки напад започети сутра рано ујутро “. Инвазија је, заправо, започела у 5 сати и 15 минута изјутра (Jeffery, 2010:415).

У марту 1940. године Фредерик Винтерботам (Frederick William Winterbotham) жалио се да је интелигентна позиција која влада према Италији „жалосна“. „Не могу да верујем““, написао је, „да су италијански официри ваздухопловства у Будимпешти, италијански инжењери и трговци у Београду и Софији неприступачни. То је страна са које треба да продремо, јер Французи максимално користе своје могућности“. Почетком маја ситуација се није поправила“" (Jeffery, 2010:423). 


\section{7. март није платила Британска влада}

Двадесет седми март је дан када је разум уступио место емоцијама. Тог дана патриоте разних политичких боја - све политичке партије изузев Љотићевог Збора - добровољачке групације, комунисти, националисти, британски и совјетски људи у војсци изводили су антиратне манифестације, након што је у ноћи пре тога извршен државни удар после потписивања Тројног пакта. Био је то први историјски корак у каснијем савезништву Британије и СССР-а и свесна српска жртва за подстицај савезницима да победе нацизам 1945. године. Сви друштвени слојеви и групе подржали су пуч и изашли на демонстрације - све политичке организације изузев љотићеваца, од патријарха Гаврила Дожића до чланова СКОЈ-а, монархисти и републиканци, русофили, франкофили, англофили, салонски интелектуалци, студенти, сељачки синови и радници. Нема ниједног јединог доказа да је било која страна влада и њена обавештајна служба организовала и била у стању да инсценира такав догађај - он је могао планути само из колективитета који почива на архетипском слободарском духу српског народа и његовом заједничком националном поносу. Одредбе Тројног пакта нису биле објављене у јавности, стога није ни била позната одредба „ни превоз трупа ни превоз ратног материјала“. У британским архивима о овом догађају и њиховом евентуалном доприносу пучу нису објављени документи. Истина је да је британска влада са 300.000 фунти помогла Републикански клуб и Земљорадничку странку, али то су били салонски академски политички клубови, пандан данашњим утицајним „тинк-тенк“ групама и политички импотентним странкама као што су у Србији деведесетих биле Грађански савез или Нова демократија. Дакле, 27. март је оригинално и оригинерно дело Срба. Можда се може говорити о совјетском и британском доприносу, али нипошто о томе да је неко „платио да Срби буду ватрене патриоте и антинацисти“. Једноставно не постоји ниједан једини релевантни историјски доказ за тај псеудомит. Тим поводом Винстон Черчил је изјавио: Early this morning the Yugoslav nation found its soul (,Југословенска нација је рано јутрос поново пронашла своју душу“).

У Другом светском рату Велика Британија је сарађивала са оба герилска ослободилачка и антинацистичка покрета, али се 
при крају рата дефинитивно определила за подршку Титовом комунистичком покрету и прекинула сарадњу са монархистичким покретом генерала Михаиловића.

\section{Закључак}

Ако се може констатовати (извући) историјска законитост која карактерише односе Велике Британије ${ }^{8}$ и Србије ${ }^{9}$, онда је то однос између, с једне стране, велике силе, колонијалне империје, велесиле и, с друге стране, једне сразмерно мале али старе, државноправном традицијом и историјом богате и велике земље, са великом и значајном улогом у историји Европе, са државом и народом високог коефицијента самопоштовања и слободарског националног поноса. Дискурс да у међународним и међудржавним односима нема ни вечитих пријатеља ни вечитих непријатеља, а да су вечити само интереси, има потврду у британско-српским односима. По историјским етапама може се, на пример, закључити да су викторијанску еру доминантно обележили добри, понекад наизглед блиски и „савезнички“ односи две државе. Након прекида дипломатских односа 1903. године због убиства краља Александра Обреновића, а потом њиховог поновног успостављања, следи ера невољног савезништва (како је то ласерски прецизно дијагностиковао академик Екмечић) током Првог светског рата. Након Великог рата и добрих али анестезираних односа између два светска рата, нису значајног утицаја на британску политику имале међудинастичке везе и културне везе два народа, као ни српска дијаспора у Великој Британији у време Другог светског рата, а посебно након њега. Одлучујући утицај Енглеза на мартовски пуч је пренаглашен - то је једноставно имагинарни мит непоткрепљен доказима. Британци нису потплатили омладину, Српску православну цркву на челу са патријархом, студенте, ђаке, интелектуалце, листом официре и политичке партије, раднике, службенике, сељаке, дакле све друштвене слојеве. Индикатор и генератор антинемачког пуча и демонстрација био је архетипски

8 Велика Британија (формирана Законима о Унији из 1707. године, енг. Acts of Union 1707) у овом тексту синоним је за Уједињено Краљевство и Уједињено Краљевство Велике Британије и Северне Ирске

9 Кнежевине Србије, Краљевине Србије, Краљевине Југославије, Социјалистичке Федеративне Републике Југославије и Савезне Републике Југославије, Републике Србије. 
српски слободарски коิд, ма колико био непромишљен. Има озбиљних мишљења да је пуч фатална српска историјска грешка која се не би догодила да је садржај Пакта био објављен: „ни превоз трупа ни превоз ратног материјала“. Наиме, изгледа да је скоро немогуће у совјетској и руској историографији наћи закључак да је Априлски рат довео до одлагања операције Барбароса. Исто је и са британском историографијом и публицистиком.

Русија је differentia specifica у српско-британским односима. Када су српско-руски односи на вишем нивоу блискости и пријатељства, и уколико је руски утицај већи, онда су британскосрпски односи лошији, и обрнуто. Ова законитост је скоро егзактно потврђена у последњих двеста година, колико и траје историја српско-британских односа. Тако је било почев од времена првог конзула Хоџиза и кнеза Милоша, преко периода друге владе Кнеза Милоша и владавине Кнеза Михаила, источне кризе, српскотурских ратова (1876-1878), Берлинског конгреса 1878. године, српско-бугарског рата 1885. године, у периоду од 1914. до 1918. године. Уочи српског напада на Бугарску 1885. године Енглези су саветовали Краља Милана да војску окрене према Старој Србији, тачније кумановској, скопској и косовској области и ослободи их, што би Велика Британија подржала. Такође, 1885. године Велика Британија је, уз Аустрију, помогла Србији да српски војнички пораз прође без територијалних казни и ратне одштете. Подсећамо да је званична Русија тада била ментор санстефанске Велике Бугарске. Тако теза да су нас „Енглези увек издали“ пада на историјском тесту. Јер, чим је Русија промотер несрпских интереса, Британија заузима „балканско небрањено шаховско поље“. Закључак осврта на историјат српско-британских односа јесте да су добри односи Велике Британије и Србије индуковани ендемском англорусофобијом, тако да су обрнуто пропорционални блиским и кохерентним српско-руским односима, односно условљени су спречавањем руског утицаја на унутрашње прилике у Србији у склопу британске средоземне политике. 


\section{Литература}

1. Растовић, А. (2000). Велика Британија и Србија 1878-1889, Историјски институт Српске академије науке и уметности, Београд.

2. Растовић, А. (2005). Велика Британија и Србија 1903-1914, Историјски институт Српске академије науке и уметности, Београд.

3. Пекић, Б. (1978). Сентиментална историја Велике Британије, Мала енциклопедија, Просвета, Београд.

4. Оташевић Б. (2013). Милован Ђилас скице за nортрет, Књижевна задруга Српског народног вијећа Црне Горе, Београд.

5. Ћоровић, В. (1989). Историја Срба, БИГЗ, Београд.

6. Ћоровић, В. (1997). Историја Српског народа, Ars Libri, Београд.

7. Група аутора, прво издање (1981-1993); друго издање (1994); треће издање (2000). Историја српског народа (I-VI), Српска књижевна задруга, Београд.

8. Живојиновић, Д. (2011). Надмени савезник и занемарено српство: британско-српски односи 1875-1941, Албатрос плус, Београд.

9. Кулаузов, М. (2019). Општа правна историја, Правни факултет, Центар за издавачку делатност, Нови Сад.

10. Екмечић, М. (2013). Дуго кретање између клања и орања, Историја Срба у новом веку 1492-1992, Evro Giunti, Београд.

11. Радојевић, М., Димић, Љ. (2014), Србија у великом рату 19141918, Српска књижевна задруга, Београд.

12. Јовић, М., Радић, К. (1990). Српске земље и владари, Друштво за неговање историјских вредности, Крушевац.

13. Аврамовић, С. (2018). Упоредна правна традиција, Универзитет у Београду Правни факултет, Центар за издаваштво и информисање, Београд.

15. Clark, C. (2012). The Sleepwalkers. How Europe Went to War in 1914, Penguin

16. Kisindžer, Н. (2017). Дипломатија, Нова књига, Подгорица.

17. Jeffery, K. (2010). MI6 the history of the secret intelligence service 1909-1949, Bloomsbury publishing Plc, London.

18. Martens, М. (2020). У пожару светова, Иво Андрић-један европски живот, Лагуна, Београд. 